\title{
Mentha pulegium crude extracts induce thiol oxidation and potentiate hemolysis when associated to t-butyl hydroperoxide in human's erythrocytes
}

\author{
MATHEUS C. BIANCHINI ${ }^{1}$, DENNYURA O. GALVÃO ${ }^{2}$, TATIANA \\ TAMBORENA ${ }^{1}$, CLAUDIA O. ALVES ${ }^{1}$ and ROBSON L. PUNTEL ${ }^{1}$ \\ ${ }^{1}$ Universidade Federal do Pampa, Campus Uruguaiana BR 472, Km 7, 97500-970 Uruguaiana, RS, Brazil \\ ${ }^{2}$ Universidade Regional do Cariri, Rua Cel. Antonio Luiz, s/n, Campus do Pimenta, 63105-000 Crato, CE, Brazil
}

Manuscript received on June 9, 2017; accepted for publication on September 1, 2017

\begin{abstract}
Mentha pulegium (Lamiaceae) tea has been used as a traditional medicine; however, the modulatory effect of M. pulegium extracts on damage to human erythrocytes associated to t-butyl hydroperoxide (t-BHP) exposure remains to be investigated. Accordingly, we perform this study in order to test the hypothesis that aqueous and ethanolic extracts of M. pulegium could modulate the hemolysis associated to t-BHP exposure, non-protein thiol (NPSH) oxidation and lipid peroxidation (measured as thiobarbituric acid reactive substances - TBARS) in human erythrocytes. Samples were co-incubated with t-BHP (4 mmol/L) and/or aqueous or ethanolic extracts $(10-1000 \mathrm{mg} / \mathrm{mL})$ during $120 \mathrm{~min}$ to further analysis. We found that both extracts, when associated to t-BHP, potentiate NPSH oxidation and hemolysis. Moreover, both extracts significantly prevents against t-BHP-induced TBARS production. A significant correlation among hemolysis and NPSH levels was found. Taking together, our data points that the association of M. pulegium extracts with t-BHP culminates in toxic effect to exposed erythrocytes, besides its protective effect against t-BHP-induced TBARS production. So, we infer that the use of this extract may exert negative effect during painful crisis in sickle cell anemia. However, more studies are still necessary to better investigate/ understand the mechanism(s) involved in the toxic effect resultant from this association.
\end{abstract}

Key words: Mentha pulegium, Lamiaceae, hemolysis, lipid peroxidation, NPSH oxidation, erythrocytes.

\section{INTRODUCTION}

The interest in research regarding pharmacological activity of plants has increased in last decades. Of particular importance, it has been recently reported that the consumption of medicinal plant extracts may exert positive effects on different models of human disorders (Martins et al. 2012, Courtes et al. 2015, Salgueiro et al. 2016). Accordingly, consumption

Correspondence to: Robson Luiz Puntel

E-mail: robson_puntel@yahoo.com.br of plant extracts supplies active compounds that may have different beneficial functions in the body (Doblado et al. 2005, Oboh 2005, 2006). Interestingly, literature data have indicated that the biological properties of different diets can be lost after isolation of specific compounds, indicating that part of their pharmacological properties can be related to a combination of different classes of such compounds (Pietrovski et al. 2006, Klimaczewski et al. 2014). As a consequence, researches with crude 
extracts (i.e. in the form that are primarily consumed by people) are necessary/useful to better address the pharmacological/toxicological of plants.

Mentha pulegium (Lamiaceae) tea has been used as a traditional medicine for the treatment of fever, pain and dysentery (Vertuani et al. 2004). Of note, $M$. pulegium was found to contain flavonoids that may account for the high antioxidant activity observed for the polar extracts of this aromatic herb (Zaidi et al. 1998, Justesen and Knuthsen 2001). Additionally, M. pulegium was reported to present anti-genotoxic effect and antiacetylcholinesterase activity (RomeroJimenez et al. 2005, Mata et al. 2007). However, to the best of our knowledge, the modulatory effect of aqueous extract (AE) and ethanolic extract (EE) from $M$. pulegium on damage to human erythrocytes associated to t-butyl hydroperoxide (t-BHP) exposure remains to be investigated.

Accordingly, erythrocytes are a convenient model to understand oxidative damage to membranes, once they are particularly sensitive. Accordingly, they have been used as a model for the investigation of free-radical induced oxidative stress due to its high amounts of polyunsaturated fatty acids, oxygen and heme (Konyalioglu and Karamenderes 2005, Nikolaidis and Jamurtas 2009). Additionally, the use of complementary/alternative models are necessary in order to preliminary determine the potential safe or risk of a great number of extracts and/or its phytoconstituents. Considering the exposed, this study was design to test the hypothesis that $\mathrm{AE}$ and $\mathrm{EE}$ of $M$. pulegium could modulate the hemolysis associated to t-BHP exposure, NPSH oxidation and lipid peroxidation in human erythrocytes.

\section{MATERIALS AND METHODS}

PLANT MATERIAL, EXTRACT PREPARATION AND QUANTIFICATION OF COMPOUNDS BY HPLC-DAD

M. pulegium was obtained from local commercial sources. Accordingly, three independent batches
(SN/132; SN/133 and SN/134) were randomly purchased and used in this study. Extracts were prepared and characterized by HPLC accordingly previously described (Tamborena et al. 2015). In short, ethanolic extract (EE) was prepared by using dried plant $(0.9 \mathrm{~g})$ that was macerated with $10 \mathrm{~mL}$ of ethanol and maintained in this solvent for further 7 days. On the $7^{\text {th }}$ day, the resulting solvent was filtered and evaporated to dryness under reduced pressure. Thereafter, the resulting pellet was re-suspended in $6.6 \mathrm{mM}$ phosphate buffer, $\mathrm{pH} 7.4$, containing 150 $\mathrm{mM} \mathrm{NaCl}$ at the same volume used to the extraction. In turn, the aqueous extract (AE) of M. pulegium was prepared by mimicking its popular use, except that phosphate buffer saline $(6.6 \mathrm{mM} ; \mathrm{pH} 7.4)$ was used in the preparation in order to avoid effect of osmolality in our experimental conditions. Briefly, $0.9 \mathrm{~g}$ of the dried plant was prepared by infusion (10 min) using $10 \mathrm{~mL}$ of $6.6 \mathrm{mM}$ phosphate buffer, $\mathrm{pH}$ 7.4 , containing $150 \mathrm{mM} \mathrm{NaCl}$. The aqueous extract was prepared just before use.

Thereafter, both $\mathrm{AE}$ and $\mathrm{EE}$ extracts from $M$. pulegium were furter analysed, for quantification of compounds by HPLC-DAD, as previously described (Tamborena et al. 2015). Accordingly, high performance liquid chromatography (HPLCDAD) was performed with a Shimadzu Prominence Auto Sampler (YL9100) HPLC system (Shimadzu, Kyoto, Japan), equipped with Shimadzu YL9110 reciprocating pumps connected to an YL9101 degasser with an YL9150 integrator, and YL9160 diode array detector. The phenolic compound profiles were determined according to the following procedure: The extracts were analyzed using a reversed phase carried out under gradient conditions using Synergi Fusion-RP 80A column $(4.6 \mathrm{~mm}$ x $250 \mathrm{~mm}$ ). The mobile phase was composed of water $(\mathrm{pH}=3)$ : acetonitrile $(5: 95, \mathrm{v} / \mathrm{v})$ in a gradient mode, until $35 \mathrm{~min}$, in which the mobile phase was $100 \%$ acetonitrile. At $38 \mathrm{~min}$ water $(\mathrm{pH}=3)$ : acetonitrile $(5: 95, \mathrm{v} / \mathrm{v})$ was used again, in isocratic mode, as a mobile phase, until 50 min. A flow rate of 0.8 
$\mathrm{ml} / \mathrm{min}$ was used, $20 \mu \mathrm{L}$ of sample were injected and the wavelengths were: $220 \mathrm{~nm}$ for gallic acid, benzoic acid, syringic and vanilic acid, and rutin; $320 \mathrm{~nm}$ for caffeic acid, cumaric acid, and ferulic acid; and $368 \mathrm{~nm}$ quercetin. Phenolic compounds were identified and quantified by comparing the retention time and UV-visible spectral data to known previously injected standards. The chromatography peaks were confirmed by comparing the retention time with those of reference standards and by DAD spectra. Calibration curve for standard compounds were performed as described previously (Tamborena et al. 2015). All chromatography operations were carried out at ambient temperature and in triplicate, revealing the presence of the rutin and benzoic acid (being rutin in greater amount as compared to benzoic acid) in both extrtacts (more details are provided in Tamborena et al. 2015); whereas gallic acid, syringic acid, vanilic acid, caffeic acid, ferulic acid, cumaric acid and quercetin were not found on these extracts.

\section{PREPARATION OF ERYTHROCYTES SUSPENSION AND EXPOSURE}

Erythrocytes were prepared and used according previously described (Santos et al. 2009). Samples were co-exposed to t-BHP $(4 \mathrm{mM})$ and/or M. pulegium extracts $(10-1000 \mu \mathrm{g} / \mathrm{mL})$ for $120 \mathrm{~min}$ at $37^{\circ} \mathrm{C}$. Thereafter, erythrocytes were washed three times with phosphate buffer saline $(6.6 \mathrm{mM}, \mathrm{pH} 7.4$, containing $150 \mathrm{mM} \mathrm{NaCl}$ ) and subsequent biochemical assays were performed as described below. The protocol was reviewed and approved by the appropriate institutional review board from Guidelines of the Committee of UNIPAMPA (127.779).

\section{BIOCHEMICAL ASSAYS}

The hemolysis test was performed accordingly to Schiar et al. 2007. The levels of non-protein thiols (NPSH) were determined accordingly to Ellmann (1959); while TBARS were determined accordingly to Ohkawa et al. 1979.

\section{STATISTICAL ANALYSIS}

Statistical significance was assessed by one way analysis of variance (ANOVA), followed by Tukey's multiple range test, when appropriate. All results were expressed as mean \pm SEM and the differences were considered significant when $\mathrm{P}<0.05$. Pearson correlation between variables was also carried out.

\section{RESULTS}

The effect of $M$. pulegium on hemolysis is depicted in Table I. Accordingly, M. pulegium $\mathrm{AE}$ (at $100 \mu \mathrm{g} / \mathrm{mL}$ - at saline ranging from 0.7 to $0.9 \%$ ) and $\mathrm{EE}$ (at $10 \mu \mathrm{g} / \mathrm{mL}$ - at saline ranging from 0.65 to $0.75 \%$; and at $100 \mu \mathrm{g} / \mathrm{mL}$ - at saline ranging from 0.65 to $0.9 \%$ ) significantly induced hemolysis under basal (without t-BHP) conditions. However, in M. pulegium treated cells the degree of hemolysis associated to t-BHP exposure was significantly higher (approximately 100\%) than that found in t-BHP treated cells, irrespective of M. pulegium and/or saline concentrations. In turn, t-BHP significantly induced hemolysis per se only at saline ranging from 0.65 to $0.75 \%$.

The effect of $M$. pulegium on basal and/or t-BHP-induced NPSH oxidation is depicted in Figure 1. Accordingly, M. pulegium AE (Figure 1a; at 10 and $100 \mu \mathrm{g} / \mathrm{mL}$ ) and EE (Figure 1b; at 10-1000 $\mu \mathrm{g} / \mathrm{mL}$ ) significantly induced NPSH oxidation in cells exposed to t-BHP. In contrast, M. pulegium AE (Figure 1a; at $1000 \mu \mathrm{g} / \mathrm{mL}$ ) significantly increases the NPSH content under basal conditions. Finally, neither EE (Figure 1b) nor t-BHP (Figure 1) significantly changed basal NPSH levels per se.

The effect of M. pulegium on basal and/or t-BHP-induced TBARS production is depicted in Figure 2. Accordingly, both M. pulegium AE (Figure $2 \mathrm{a}$ ) and EE (Figure $2 \mathrm{~b}$ ) significantly prevent the t-BHP-induced TBARS production, being without effect on basal TBARS levels (Figure 2).

Finally, Table II summarizes the correlations among NPSH content and/or TBARS on hemolysis. 
TABLE I

Effect of M. pulegium AE and EE on basal and/or t-BHP associated hemolysis.

\begin{tabular}{|c|c|c|c|c|c|}
\hline \multirow[b]{2}{*}{ Saline concentration } & \multirow[b]{2}{*}{$\mathrm{mg} / \mathrm{mL}$ of Dried Plant } & \multicolumn{2}{|c|}{ Without t-BHP } & \multicolumn{2}{|c|}{ With t-BHP } \\
\hline & & Aqueous Extract & Ethanolic Extract & Aqueous Extract & Ethanolic Extract \\
\hline \multirow{4}{*}{$0.4 \%$} & 0 & $38,62 \pm 3,581$ & $32,51 \pm 4,122$ & $99,55 \pm 4,389^{\#}$ & $95,46 \pm 0,738^{\#}$ \\
\hline & 10 & $56,68 \pm 3,294 *$ & $65,12 \pm 3,206^{*}$ & $98,89 \pm 0,443$ & $98,53 \pm 0,435$ \\
\hline & 100 & $48,37 \pm 3,019$ & $53,14 \pm 1,808^{*}$ & $99,62 \pm 0,090$ & $99,54 \pm 0,002$ \\
\hline & 1000 & $59,48 \pm 4,487^{*}$ & $62,96 \pm 1,429^{*}$ & $99,67 \pm 0,375$ & $98,74 \pm 0,046$ \\
\hline \multirow{4}{*}{$0.65 \%$} & 0 & $11,71 \pm 2,763$ & $11,51 \pm 2,763$ & $27,44 \pm 3,045 \#$ & $27,24 \pm 4,244^{\#}$ \\
\hline & 10 & $25,97 \pm 4,792$ & $30,26 \pm 2,148^{*}$ & $98,66 \pm 0,660 *$ & $97,91 \pm 0,341 *$ \\
\hline & 100 & $24,18 \pm 4,569$ & $35,17 \pm 2,211 *$ & $99,67 \pm 0,077 *$ & $99,54 \pm 0,002 *$ \\
\hline & 1000 & $25,43 \pm 6,028$ & $17,27 \pm 0,616$ & $99,32 \pm 0,395^{*}$ & $99,05 \pm 0,0347 *$ \\
\hline \multirow{4}{*}{$0.7 \%$} & 0 & $8,210 \pm 2,474$ & $8,224 \pm 3,600$ & $21,35 \pm 3,192^{\#}$ & $21,33 \pm 3,598^{\#}$ \\
\hline & 10 & $19,11 \pm 4,055$ & $24,77 \pm 2,705^{*}$ & $98,55 \pm 0,595^{*}$ & $97,91 \pm 0,341 *$ \\
\hline & 100 & $21,59 \pm 4,834^{*}$ & $34,04 \pm 2,471^{*}$ & $99,69 \pm 0,100 *$ & $99,85 \pm 0,009 *$ \\
\hline & 1000 & $16,22 \pm 2,737$ & $14,85 \pm 1,032$ & $99,03 \pm 0,378^{*}$ & $99,21 \pm 0,028 *$ \\
\hline \multirow{4}{*}{$0.75 \%$} & 0 & $7,440 \pm 2,634$ & $7,403 \pm 3,957$ & $18,77 \pm 2,747 \#$ & $18,97 \pm 3,616^{\#}$ \\
\hline & 10 & $18,25 \pm 4,064$ & $23,46 \pm 2,233^{*}$ & $98,56 \pm 0,619^{*}$ & $97,91 \pm 0,341 *$ \\
\hline & 100 & $20,86 \pm 4,789 *$ & $33,36 \pm 2,836^{*}$ & $99,69 \pm 0,100 *$ & $100,0 \pm 0,307 *$ \\
\hline & 1000 & $14,42 \pm 2,663$ & $15,12 \pm 0,743$ & $99,31 \pm 0,446^{*}$ & $99,86 \pm 0,303 *$ \\
\hline \multirow{4}{*}{$0.8 \%$} & 0 & $10,311 \pm 2,382$ & $10,62 \pm 5,781$ & $16,12 \pm 2,311$ & $16,45 \pm 1,337$ \\
\hline & 10 & $16,81 \pm 3,617$ & $21,47 \pm 0,862$ & $98,50 \pm 0,604^{*}$ & $98,28 \pm 0,619 *$ \\
\hline & 100 & $19,67 \pm 4,777 *$ & $33,36 \pm 2,836^{*}$ & $99,67 \pm 0,077 *$ & $100,2 \pm 0,399 *$ \\
\hline & 1000 & $12,23 \pm 2,282$ & $14,96 \pm 0,739$ & $99,16 \pm 0,428^{*}$ & $99,54 \pm 0,300 *$ \\
\hline \multirow{4}{*}{$0.9 \%$} & 0 & $9,568 \pm 2,510$ & $9,45 \pm 5,436$ & $14,69 \pm 4,650$ & $14,34 \pm 0,888$ \\
\hline & 10 & $13,71 \pm 2,751$ & $20,28 \pm 0,815$ & $98,44 \pm 0,617 *$ & $99,04 \pm 0,649 *$ \\
\hline & 100 & $18,11 \pm 4,454^{*}$ & $38,47 \pm 4,605^{*}$ & $99,53 \pm 0,162 *$ & $99,69 \pm 0,308 *$ \\
\hline & 1000 & $10,99 \pm 1,940$ & $15,22 \pm 0,565$ & $99,13 \pm 0,414 *$ & $99,70 \pm 0,301 *$ \\
\hline
\end{tabular}

The values are expressed $\%$ of control (samples exposed to saline $0 \%$ were considered with $100 \%$ of hemolysis); ( $\mathrm{n}=6$ ). * indicates differences respective control (without M. pulegium extracts) by one-way ANOVA following by Tukey's test. \# indicates differences among control (without plant extracts) and t-BHP by one-way ANOVA following by Tukey's test.

In short, we found that NPSH content was negatively and significantly associated with hemolysis, at all saline concentrations and both in $\mathrm{AE}$ and $\mathrm{EE}$ of $M$. pulegium. In turn, TBARS was found to be practically not correlated to hemolysis, except at saline $0.4 \%$ (both $\mathrm{AE}$ and $\mathrm{EE}$ ) and at saline $0.9 \%$ (only EE) in which TBARS levels were positively and significantly associated with hemolysis (Table II).

\section{DISCUSSION}

We found here that the exposure to t-BHP increased TBARS levels and makes erythrocytes more prone to hemolysis when exposed to low saline $(0,4 \%$ - 0,75\%). Importantly, t-BHP does not induce hemolysis per se at saline ranging from $0.8 \%$ to $0.9 \%$, and does not induced NPSH oxidation. Accordingly, we suggest that the t-BHP-induced damage to lipids (evaluated here as TBARS) weakens the membrane making cells more susceptible to hemolysis at lower saline, which are in accordance to literature (Trotta et al. 1983, Itri et al. 2014). In turn, we found here that t-BHP does not increase NPSH oxidation and methaemoglobin content (data not shown) under our experimental 
a

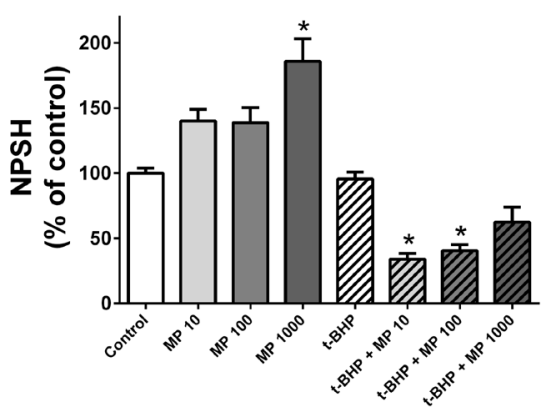

b

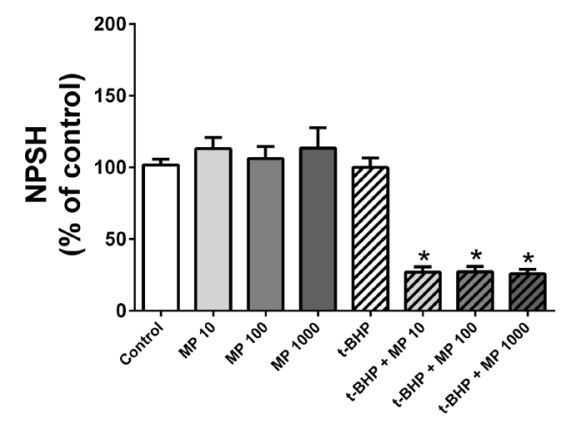

Figure 1 - Effect of $M$. pulegium AE (a) and EE (b) on basal and/or t-BHP-induced NPSH oxidation in erythrocytes. * indicates statistical difference $(\mathrm{P}<0.05)$ from respective control (i.e. from basal or from t-BHP); $\mathrm{n}=5 ; \mathrm{MP}=$ Mentha pulegium.

conditions, contrasting to previous data (Trotta et al. 1983, Adesanoye et al. 2013, Portela et al. 2017).

Our data also confirms the hypothesis that both $\mathrm{AE}$ and EE extracts of M. pulegium could modulate the oxidative changes associated to t-BHP exposure in human erythrocytes. Our data also supports the notion that hemolysis is significantly correlated to NPSH content and (at some extent) to TBARS. Anyway, we cannot exclude the possibility that other(s) mechanism(s) is(are) also involved in hemolysis. Importantly, we suggest that the putative incorporation of phenolic compounds from extracts in the membranes of erythrocytes can also contribute to hemolysis (both in non-exposed a

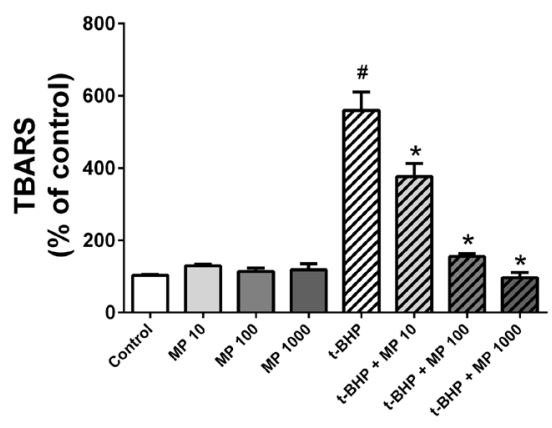

b

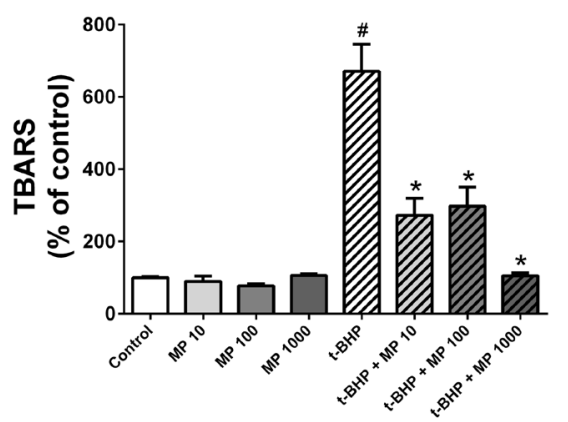

Figure 2 - Effect of $M$. pulegium AE (a) and EE (b) on basal and/or t-BHP-induced TBARS production. * indicates statistical difference $(\mathrm{p}<0.05)$ from respective control (i.e. from basal or from $\mathrm{t}$-BHP). \# indicates statistical difference $(\mathrm{P}<0.05)$ from basal; $\mathrm{n}=5 ; \mathrm{MP}=$ Mentha pulegium .

and exposed erythrocytes), which is in accordance to literature (Bors et al. 2012, Duchnowicz et al. 2012). On the other hand, it cannot be excluded that incorporation of phenolic compounds contained in extracts can also positively influence the red blood cells (Bors et al. 2012, Wloch et al. 2016). Of note, differences in the chemical structure of phenolic are critical to determine the type of interactions that occurs between these compounds and membrane surface (Oteiza et al. 2005, Hendrich 2006, Bors et al. 2012, Duchnowicz et al. 2012).

In line with this, rutin (also called quercetin3-O-rutinoside; one of the major metabolites found in M. pulegium extracts - see Tamborena et al. 
TABLE II

Pearson correlations between saline concentration and NPSH or TBARS content.

\begin{tabular}{|c|c|c|c|c|c|c|}
\hline Saline concentration & $0.4 \%$ & $0.65 \%$ & $0.7 \%$ & $0.75 \%$ & $0.8 \%$ & $0.9 \%$ \\
\hline \multicolumn{7}{|c|}{ Aqueous Extract } \\
\hline & $-0.4112 *$ & $-0.6601^{*}$ & $-0.6808^{*}$ & $-0.6834 *$ & $-0.6925^{*}$ & $-0.6621 *$ \\
\hline NPSH content & $\mathrm{P}=0,0084$ & $\mathrm{P}<0,0001$ & $\mathrm{P}<0,0001$ & $\mathrm{P}<0,0001$ & $\mathrm{P}<0,0001$ & $\mathrm{P}<0,0001$ \\
\hline \multirow{2}{*}{ TBARS } & $0.5218^{*}$ & 0.0837 & 0.0754 & 0.0572 & 0.0468 & 0.1880 \\
\hline & $\mathrm{P}=0,0006$ & $\mathrm{P}=0,6076$ & $\mathrm{P}=0,6435$ & $\mathrm{P}=0,7257$ & $\mathrm{P}=0,7743$ & $\mathrm{P}=0,2453$ \\
\hline \multicolumn{7}{|c|}{ Ethanolic Extract } \\
\hline & $-0.4588 *$ & $-0.6909 *$ & $-0.6914^{*}$ & $-0.6929 *$ & $-0.7035^{*}$ & $-0.5400^{*}$ \\
\hline NPSH content & $\mathrm{P}=0,0029$ & $\mathrm{P}<0,0001$ & $\mathrm{P}<0,0001$ & $\mathrm{P}<0,0001$ & $\mathrm{P}<0,0001$ & $\mathrm{P}=0,0003$ \\
\hline \multirow{2}{*}{ TBARS } & $0.5142 *$ & 0.0251 & 0.0075 & 0.0030 & 0.0115 & $0.4912^{*}$ \\
\hline & $\mathrm{P}=0,0007$ & $\mathrm{P}=0,8778$ & $\mathrm{P}=0,9630$ & $\mathrm{P}=0,9851$ & $\mathrm{P}=0,9439$ & $\mathrm{P}=0,0013$ \\
\hline
\end{tabular}

2015) was previously found to modify membranedependent processes, such as the lipid peroxidation (Saija et al. 1995). In the same study, authors suggest that this effect could be related not only to their structural characteristics but also to their ability to interact with and also penetrate the lipid bilayers (Saija et al. 1995), reinforcing our assumption that $M$. pulegium extracts could induce hemolysis due to membrane destabilization/disorganization (due to interaction among phospholipids and phytochemicals), at the same time that prevent TBARS production due to its antioxidant activity. Similarly, it was previously found that quercetin (a phenolic compound structuraly related to rutin) leads to a significant changes in size and shape of the treated erythrocytes (Pawlikowska-Pawlega et al. 2003, Bors et al. 2012). Of particular importance, the effect of quercetin was due to its incorporation into erythrocyte membrane and also due to its interaction with cytoskeleton proteins. Indeed, it was previously shown that cytoskeletal proteins and integral membrane proteins are responsible for maintaining of erythrocytes morphology (Sato et al. 1986, Bors et al. 2012).

Both $\mathrm{AE}$ and $\mathrm{EE}$ from M. pulegium were found also to produce protective effect against
t-BHP-induced TBARS production, which may be attributed to its antioxidant potential (Jain et al. 2012, Brahmi et al. 2017). Accordingly, it is reasonable to conclude that both extracts from this plant protects erythrocytes from lipid damage cased by t-BHP. On the other hand, our results allow us to also suggest that both extracts enhances t-BHPinduced hemolysis by forming a complex(es) with cell components released during damage mediated by t-BHP, which are believed to destabilizes the cell membrane, accordingly to previously described (Huy et al. 2002, 2004, Lisovskaya et al. 2009).

Importantly, the potentiation in the t-BHPinduced hemolysis, by both extracts from $M$. pulegium, allows us to suggest that this plant may act as a cytotoxic agent in pathologies associated with oxidative stress and increased blood cells damaged (e.g., intravascular hemolysis and others). As a consequence, the implications of these findings may be double-faced. Indeed, the use of this extract may have/exert negative/adverse effect during painful crisis in sickle cell anemia, similar to caffeine (Wang et al. 2009). In contrast, the effect of this plant on membrane of blood cells may be employed to increase the efficacy of antitumor 
therapy, accordingly to previous report (Elsyana et al. 2016, Saghir et al. 2016, Tabrizi et al. 2016).

The potentiation in NPSH and in the hemolysis in erythrocytes treated with plant extracts and t-BHP deserves, doubtless, further research to investigate the involved mechanism(s). Likewise, the increase in NPSH content in erythrocytes treated with $\mathrm{AE}$ of this plant needs to be further addressed. Importantly, with respect to increase in NPSH content, it was previously found that erythrocytes exposed to Bauhinia forficata and to Ilex paraguariensis aqueous extracts, under in vitro conditions, were found to have an increase in NPSH content (Salgueiro et al. 2013, Portela et al. 2017), which is similar to results present here.

In conclusion, we found here that association of AE or EE from M. pulegium with t-BHP makes erythrocytes more prone to hemolysis, which was significantly correlated to NPSH oxidation, besides protective effect against t-BHP-induced TBARS.

\section{ACKNOWLEDGMENTS}

The authors are grateful to Coordenação de Aperfeiçoamento Pessoal de Nível Superior (CAPES), Financiadora de Estudos e Projetos (FINEP), Instituto Nacional de Ciência e Tecnologia - Excitotoxicidade e Neuroproteção (INCT-EN), UNIPAMPA, CNPq/FAPERGS/DECIT/SCTIEMS/PRONEM \#11/2029-1 and CNPq/Universal $\# 449428 / 2014-1$. The authors declare that there is no conflict of interest.

\section{REFERENCES}

ADESANOYE OA, MOLEHIN OR, DELIMA AA, ADEFEGHA AS AND FAROMBI EO. 2013. Modulatory effect of methanolic extract of Vernonia amygdalina (MEVA) on tert-butyl-hydroperoxide-induced erythrocyte haemolysis. Cell Biochem Funct 31: 545-550.

BORS M, SICINSKA P, MICHALOWICZ J, WIETESKA P, GULEWICZ K AND BUKOWSKA B. 2012. Evaluation of the effect of Uncaria tomentosa extracts on the size and shape of human erythrocytes (in vitro). Environ Toxicol Pharmacol 33: 127-134.
BRAHMI F, DAHMOUNE F, KADRI N, CHIBANE M, DAIRI S, REMINI H, OUKMANOU-BENSIDHOUM S, MOUNI L AND MADANI K. 2017. Antioxidant capacity and phenolic content of two Algerian Mentha species $M$. rotundifolia (L.) Huds, M. pulegium L., extracted with different solvents. J Compl Int Med: 1553-3840.

COURTES AA, ARANTES LP, BARCELOS RP, DA SILVA IK, BOLIGON AA, ATHAYDE ML, PUNTEL RL AND SOARES FAA. 2015. Protective effects of aqueous extract of Luehea divaricata against behavioral and oxidative changes induced by 3-nitropropionic acid in rats. Evid Based Complement Alternat Med 2015: 723431.

DOBLADO R, ZIELINSKI H, PISKULA M, KOZLOWSKA H, MUNOZ R, FRIAS J AND VIDAL-VALVERDE C. 2005. Effect of processing on the antioxidant vitamins and antioxidant capacity of Vigna sinensis Var. Carilla. J Agric Food Chem 53: 1215-1222.

DUCHNOWICZ P, BORS M, PODSEDEK A, KOTERMICHALAK M AND BRONCEL M. 2012. Effect of polyphenols extracts from Brassica vegetables on erythrocyte membranes (in vitro study). Environ Toxicol Pharmacol 34: 783-790.

ELLMAN GL 1959. Tissue sulfhydryl groups. Arch Biochem Biophys 82: 70-77.

ELSYANA V, BINTANG M AND PRIOSOERYANTO BP. 2016. Cytotoxicity and antiproliferative activity assay of Clove mistletoe (Dendrophthoe pentandra (L.) Miq.) leaves extracts. Adv Pharmacol Sci 2016: 3242698.

HENDRICH AB. 2006. Flavonoid-membrane interactions: possible consequences for biological effects of some polyphenolic compounds. Acta Pharmacol Sin 27: 27-40.

HUY NT, KAMEI K, YAMAMOTO T, KONDO Y, KANAORI K, TAKANO R, TAJIMA K AND HARA S. 2002. Clotrimazole binds to heme and enhances hemedependent hemolysis: proposed antimalarial mechanism of clotrimazole. J Biol Chem 277: 4152-4158.

HUY NT, TAKANO R, HARA S AND KAMEI K. 2004. Enhancement of heme-induced membrane damage by the anti-malarial clotrimazole: the role of colloid-osmotic forces. Biol Pharm Bull 27: 361.E-365.E.

ITRI R, JUNQUEIRA HC, MERTINS O AND BAPTISTA MS. 2014. Membrane changes under oxidative stress: the impact of oxidized lipids. Biophys Rev 6: 47-61.

JAIN S, JAIN DK AND BALEKAR N. 2012. In-vivo antioxidant activity of ethanolic extract of Mentha pulegium leaf against $\mathrm{CCl}_{4}$ induced toxicity in rats. Asian Pacific J Trop Bio 2(2): S737-S740.

JUSTESEN U AND KNUTHSEN P. 2001. Composition of flavonoids in fresh herbs and calculation of flavonoid intake by use of herbs in traditional Danish dishes. Food Chem 73: 245-250.

KLIMACZEWSKI CV, SARAIVARA, ROOS DH, BOLIGON A, ATHAYDE ML, KAMDEM JP, BARBOSA NV AND 
ROCHA JBT. 2014. Antioxidant activity of Peumus boldus extract and alkaloid boldine against damage induced by $\mathrm{Fe}(\mathrm{II})-$ citrate in rat liver mitochondriain vitro. Ind Crops Prod 54: 240-247.

KONYALIOGLU S AND KARAMENDERES C. 2005. The protective effects of Achillea L. species native in Turkey against $\mathrm{H}(2) \mathrm{O}(2)$-induced oxidative damage in human erythrocytes and leucocytes. J Ethnopharmacol 102: 221227.

LISOVSKAYA IL, SHCHERBACHENKO IM, VOLKOVA RI AND ATAULLAKHANOV FI. 2009. Clotrimazole enhances lysis of human erythrocytes induded by t-BHP. Chem Biol Int 180: 433-439.

MARTINS EN, PESSANO NTC, LEAL L, ROOS DH, FOLMER V, PUNTEL GO, ROCHA JBT, ASCHNER M, AVILA DS AND PUNTEL RL 2012. Protective effect of Melissa officinalis aqueous extract against Mn-induced oxidative stress in chronically exposed mice. Brain Res Bull 87: 74-79.

MATA AT, PROENÇA C, FERREIRA AR, SERRALHEIRO MLM, NOGUEIRA JMF AND ARAÚJO MEM. 2007. Antioxidant and antiacetylcholinesterase activities of five plants used as Portuguese food spices. Food Chem 103: 778-786.

NIKOLAIDIS MG AND JAMURTAS AZ. 2009. Blood as a reactive species generator and redox status regulator during exercise. Arch Biochem Biophys 490: 77-84.

OBOH G. 2005. Hepatoprotective property of ethanolic and aqueous extracts of fluted pumpkin (Telfairia occidentalis) leaves against garlic-induced oxidative stress. J Med Food 8: 560-563.

OBOH G. 2006. Nutritive value, antioxidant and antimicrobial properties of Struchium sparganophora leaves. J Med Food 9: 276-280.

OHKAWA H, OHISHI N AND YAGI K. 1979. Assay for lipid peroxides in animal tissues by thiobarbituric acid reaction. Anal Biochem 95: 351-358.

OTEIZA PI, ERLEJMAN AG, VERSTRAETEN SV, KEEN CL AND FRAGA CG. 2005. Flavonoid-membrane interactions: a protective role of flavonoids at the membrane surface? Clin Develop Immunol 12: 19-25.

PAWLIKOWSKA-PAWLEGA B, GRUSZECKI W, MISIAK L AND GAWRON A. 2003. The study of the quercetin action on human erythrocyte membranes. Biochem Pharmacol 66: 605-612.

PIETROVSKI EF, ROSA KA, FACUNDO VA, RIOS K, MARQUES MC. AND SANTOS AR. 2006. Antinociceptive properties of the ethanolic extract and of the triterpene 3beta,6beta,16beta-trihidroxilup-20(29)ene obtained from the flowers of Combretum leprosum in mice. Pharmacol Biochem Behav 83: 90-99.

PORTELA JL, SOARES D, ROSA H, ROOS DH, PINTON S, ÁVILA DS AND PUNTEL RL. 2017. Ilex paraguariensis crude extract acts on protection and reversion from damage induced by t-butyl hydroperoxide in human erythrocytes: a comparative study with isolated caffeic and/or chlorogenic acids. J Sci Food Agric 97: 2007-2014.

ROMERO-JIMENEZ M, CAMPOS-SANCHEZ J, ANALLA M, MUNOZ-SERRANO A AND ALONSO-MORAGA A. 2005. Genotoxicity and anti-genotoxicity of some traditional medicinal herbs. Mutat Res 585: 147-155.

SAGHIR SS, SADIKUN A, AL-SUEDE FS, ABDUL MAJID AM AND MURUGAIYAH V. 2016. Antihyperlipidemic, antioxidant and cytotoxic activities of methanolic and aqueous extracts of different parts of star fruit. Curr Pharm Biotechnol 17: 915-925.

SAIJA A, SCALESE M, LANZA M, MARZULLO D, BONINA F AND CASTELLI F. 1995. Flavonoids as antioxidant agents: importance of their interaction with biomembranes. Free Radic Biol Med 19: 481-486.

SALGUEIRO AC, FOLMER V, DA SILVA MP, MENDEZ AS, ZEMOLIN AP, POSSER T, FRANCO JL, PUNTEL RLAND PUNTEL GO. 2016. Effects of Bauhinia forficata tea on oxidative stress and liver damage in diabetic mice. Oxidative Med Cell Longev 2016: 8902954.

SALGUEIRO AC, LEAL CQ, BIANCHINI MC, PRADO IO, MENDEZ AS, PUNTEL RL, FOLMER V, SOARES FAS, AVILA DS AND PUNTEL GO. 2013. The influence of Bauhinia forficata Link subsp. pruinosa tea on lipid peroxidation and non-protein $\mathrm{SH}$ groups in human erythrocytes exposed to high glucose concentrations. J Ethnopharmacol 148: 81-87.

SANTOS DB, SCHIAR VP, PAIXAO MW, MEINERZ DF, NOGUEIRA CW, ASCHNER M, ROCHA JBT AND BARBOSA NB. 2009. Hemolytic and genotoxic evaluation of organochalcogens in human blood cells in vitro. Toxicol In Vitro 23: 1195-1204.

SATO S, JINBU Y AND NAKAO M. 1986. Characterization of human erythrocyte cytoskeletal ATPase. J Biochem 100: 643-649.

SCHIAR VP, DOS SANTOS DB, LUDTKE DS, VARGAS F, PAIXAO MW, NOGUEIRA CW, ZENI G AND ROCHA JBT. 2007. Screening of potentially toxic chalcogens in erythrocytes. Toxicol In Vitro 21: 139-145.

TABRIZI FH, IRIAN S, AMANZADEH A, HEIDARNEJAD F, GUDARZI H AND SALIMI M. 2016. Anti-proliferative activity of Fumaria vaillantii extracts on different cancer cell lines. Res Pharm Sci 11: 152-159.

TAMBORENA T, GULARTE CAO, ESCOTO DF, GAYER MC, ROEHRS R, FOLMER V, AVILA DS AND PUNTEL RL. 2015. Antioxidant activity of some medicinal plant extracts: implications for neuroprotection. Pharmacologia 6: 282-292.

TROTTA RJ, SULLIVAN SG AND STERN A. 1983. Lipid peroxidation and haemoglobin degradation in red blood 
cells exposed to t-butyl hydroperoxide. The relative roles of haem- and glutathione-dependent decomposition of t-butyl hydroperoxide and membrane lipid hydroperoxides in lipid peroxidation and haemolysis. Biochem J 212: 759772.

VERTUANI S, ANGUSTI A AND MANFREDINI S. 2004. The antioxidants and pro-antioxidants network: an overview. Curr Pharm Des 10: 1677-1694.
WANG YQ, ZHANG HM AND ZHOU QH. 2009. Studies on the interaction of caffeine with bovine hemoglobin. Eur $\mathrm{J}$ Med Chem 44: 2100-2105.

WLOCH A, STRUGALA P, PRUCHNIK H, ZYLKA R, OSZMIANSKI J AND KLESZCZYNSKA H. 2016. Physical effects of buckwheat extract on biological membrane in vitro and its protective properties. J Membrane Biol 249: 155-170. 